\title{
PEMBELAJARAN REFLEKTIF: UPAYA MEMBUMIKAN HERMENEUTIK DALAM PRAKTIK PENDIDIKAN
}

\author{
Saptono \\ LP3S Salatiga \\ saptono_67@yahoo.co.id
}

\begin{abstract}
ABSTRAK
Hermeneutik merupakan refleksi kritis untuk menafsirkan teks/realitas dan memahami maknanya. Melalui hermeneutik orang diajak untuk terus-menerus bergerak dari refleksi menuju aksi, demikian pula sebaliknya, demi pengembangan diri dan transformasi masyarakat/budaya. Walaupun merupakan wacana kefilsafatan, hermeneutik tidak semata-mata bersifat teoretis, melainkan memiliki implikasi praktis dalam pendidikan. Tulisan ini mencoba merekonstruksi kaitan antara hermeneutik dengan praktik pembelajaran, dalam hal ini Pembelajaran Reflektif.
\end{abstract}

Kata kunci: hermeneutik, teks, penafsiran, makna, konteks, pengalaman, refleksi, aksi, evaluasi.

\section{PENDAHULUAN}

Hermeneutik merupakan tema lama dalam wacana keilmuan, yang telah dikembangkan sejak jaman kuno dalam praktik pendidikan di Alexandria. Hermeneutik menjadi bagian dari budaya teologi yang berkembang pada Abad Pertengahan di Eropa, dan semakin dikembangkan oleh kalangan Protestan untuk kepentingan penafsiran Kitab Suci. Selain itu, hermeneutik juga dikembangkan dalam tiga bidang lain, yaitu: filologi klasik, hukum dan filsafat. Pada akhirnya, dalam semangat para filsufAbad Pencerahan untuk mensistematisasikan pengetahuan, hermeneutik menjadi bidang garapan filsafat.

Meskipun hermeneutik merupakan tema lama, namun ia memperoleh vitalitas dan aktualitasnya dalam kancah wacana keilmuan kontemporer, terutama ilmu-ilmu kemanusiaan (Geisteswissenschaften). Dalam hal ini, Moeller-Vollmer(1985:ix) misalnya, mencatat demikian, "Today the term hermeneutics denotes a concern that is shared by members of such diverse fields of knowledge as philosophy, sociology, history, theology, psychology, jurisprudence, literary criticism, and humanities at large". Mengapa hermeneutik memiliki pengaruh sedemikian luas dalam wacana keilmuan? Karena, "...paradigma tersebut merupakan salah satu sudut pandang yang paling meyakinkan untuk memandang segala persoalan kontemporer secara baru" (Sugiharto:1996:32). Boleh jadi ungkapan tersebut berlebihan, tetapi setidaknya itu mengindikasikan tentang arti penting hermeneutik dalam wacana keilmuan kontemporer. Meskipun hermeneutik merupakan tema lama, namun tetap aktual.

Disadari, spektrum wacana tentang hermeneutik sesungguhnya amatlah luas dan rumit. Oleh karena itu, tulisan ini tidak akan masuk dalam uraian mengenai keluasan dan kompleksitas wacana mengenai hermeneutik. Tulisan ini hanya akan membatasi diri pada perbincangan tentang hermeneutik (modern) dan kaitannya dengan upaya untuk membumikannya dalam praktik pendidikan. Di sini tidak dibahas hermeneutik posmodern yang umumnya dianggap dapat direpresentasikan oleh pemikiran Lacan, Derrida, Lyotard, Foucault dan Rorty. Selanjutnya, periksa Robin Usher \& Richard Edwards.1994. Postmodernism and Education: Different voices, different worlds. London: Routledge 


\section{UPAYA MEMAHAMI TEKS}

Istilah "hermeneutik" (Inggris: hermeneutics) berasal dari kata kerja dalam bahasa Yunani hermeneuô, yang berarti mengartikan, menginterpretasikan, menafsirkan, atau menerjemahkan (Bertens, 2002: 257). Istilah tersebut erat kaitannya dengan kisah tentang Hermes, seorang tokoh dalam mitologi Yunani.

Hermes digambarkan sebagai seorang manusia yang memiliki kaki bersayap. Ia adalah utusan Jupiter yang bertugas menyampaikan pesan-pesan para dewa di Gunung Olympus kepada manusia. Pesan para dewa itu seringkali memiliki berbagai macam makna. Karena itu, berhasil tidaknya Hermes dalam menyampaikan pesan itu tergantung pada kemampuannya dalam menafsirkan makna dan menyampaikan pesan tersebut kepada manusia.

Terkait dengan tugas Hermes dalam mitologi itu, secara umum hermeneutik lantas diartikan sebagai "proses mengubah situasi ketidakmengertian menjadi mengerti" (Sumaryono, 1996:24) atau "proses membuat sesuatu yang tidak jelas menjadi jelas" (Neuman, 2000:70). Sedangkan dalam wacana filsafat, istilah "hermeneutik" dipakai untuk menunjuk semua tema filosofis sejauh terkait dengan persoalan "bahasa" (Bertens, 2002: 257).

Pada dasarnya hermeneutik merupakan refleksi tentang upaya "memahami" (verstehen). Memahami tentang apa? Menurut Paul Ricoeur(1991:53,106), hermeneutik merupakan teori tentang upaya "memahami”" teks. Teks itu menunjuk pada segala wacana. Teks itu bisa berupa tulisan, lambanglambang, simbol-simbol dan juga arus sejarah. Sehingga, hermeneutik merupakan metode yang memungkinkan kita menjadi sadar dan mengerti akan proses-proses kebudayaan (van Peuersen, 1985:246). Hermeneutik adalah refleksi kritis atas cara-cara kita memahami dunia dan atas bentukbentuk ungkapan pemahaman itu. Adapun objek utama hermeneutik adalah segala bentuk "teks" yang memungkinkan manusia memahami dunia dan dirinya sendiri (Sugiharto, 1996:38).

\section{BELANTARA HERMENEUTIK}

Schleiermacher (1768-1834) adalah teolog cum filsuf yang meletakkan dasar bagi dimulainya hermeneutik modern (Braum \& Bauer, dalam Ricoeur, 1991:58). Melalui pemikiran Schleiermacher, hermeneutik mengalami pergeseran fokus secara signifikan. Sebelumnya, hermeneutik berfokus pada analisis teks tertulis yang berasal dari masa lalu. Lantas, hermeneutik berfokus pada analisis tentang bagaimana orang dari sebuah lingkungan budaya memahami pengalaman orang lain yang berasal dari lingkungan budaya yang berbeda, atau bagaimana seseorang yang hidup dalam satu kurun sejarah tertentu memahami kehidupan dari mereka yang berada dalam kurun sejarah yang berbeda (Blaikie, 1993:29).

Bagi Schleiermacher upaya untuk memahami mempunyai dua dimensi, yaitu interpretasi gramatika dan interpretasi psikologis (Moeller-Vollmer, 1985: 74-76). Melalui interpretasi gramatika, orang memahami dimensi bahasa dari teks. Melalui interpretasi psikologis, orang berupaya mengalami kembali proses mental dari penulis teks atau melakukan perbincangan dengan pelaku sosial. Adapun tugas hermeneutik, menurut Schleiermacher, adalah "memahami makna teks sebaik atau lebih baik dari pengarangnya sendiri" (Moeller-Vollmer, 1985: 83). Untuk itu, pembaca perlu mulai memahami keseluruhan yang tak terpahami dengan memahami bagian-bagian yang dapat dipahami. Selanjutnya, pembaca harus mencoba memahami tiap-tiap bagian dalam kaitannya dengan keseluruhan, demikian pula sebaliknya, ia perlu memahami keseluruhan dalam kaitannya dengan tiap bagian yang menyusunnya. Dengan kata lain, setiap bagian harus dipahami dalam konteks atau dalam lingkaran hermeneutik. 
Hermeneutik modern sebagaimana dikembangkan Schleiermacher, di kemudian hari dilanjutkan dan semakin diteguhkan oleh Wilhelm Dilthey(1833-1911). Adapun inti dari pandangan hermeneutik Schleiermacher dan Dilthey adalah, bahwa memahami sebuah teks berarti menemukan makna asli sebagaimana dimaksudkan oleh penulisnya. Jadi, hermeneutik merupakan kegiatan rekonstruksi dan reproduksi makna. Karena itu, untuk memperoleh penafsiran yang benar, seorang penafsir harus sanggup "melepaskan diri” dari situasi historisnya dan "berpindah" ke situasi historis lain, yaitu situasi historis penulisnya.

Bertolak dari pandangan Schleiermacher dan Dilthey, hermeneutik terus berkembang hingga sekarang ini. Sejumlah pemikir amat berjasa dalam mengembangkan hermeneutik ini. Martin Heidegger (1889-1976) dan Hans-Georg Gadamer (1900) memiliki tempat tersendiri dalam kancah perkembangan hermeneutik pasca Schleiermacher dan Dilthey. Sebab, melalui pemikiran merekalah hermeneutik mengalami pergeseran penting dari wilayah epistemologi ke wilayah ontologi (Ricoeur, 1991:63-73). Demikianlah, perkembangan hermeneutik lebih lanjut bersandar pada dua arus utama, yaitu pemikiran Schleiermacher dan Dilthey di satu sisi, dan di sisi lain pemikiran Heidegger dan Gadamer. Arus pemikiran pertama cenderung menekankan hermeneutik dalam dimensi metodologis, sedangkan yang kedua cenderung menekankan hermeneutik dalam perspektif ontologis.

Patut dicatat, pemikiran tentang hermeneutik bisa diibaratkan sebagai hutan belantara yang terdiri dari berbagai jenis pohon. Tiap-tiap pemikir/filsuf hermeneutik mengembangkan corak pemikiran khas masing-masing. Satu sama lain berbeda, bahkan ada kalanya bertentangan. Inilah salah satu kesulitan untuk memperoleh gambaran umum mengenai hermeneutik modern.

Karena itu, tidak bisa lain, untuk memperoleh gambaran umum mengenai hermeneutik kita perlu melakukan generalisasi dan penyederhanaan, dengan cara mengelompokkan dan meringkaskan berbagai pemikiran khas itu dalam beberapa gugus. Roy J. Howard (2000) misalnya, telah mencoba mengelompokkan pemikiran hermeneutik dalam tiga gugus, yaitu hermeneutik analitis (von Wright, Winch), hermeneutik psikososial (Habermas) dan hermeneutik ontologis (Dilthey, Gadamer). Sementara itu, Bambang Sugiharto (1996) membedakan dalam dua kelompok besar, yaitu hermeneutik dekonstruktif (Derrida, Lyotard, Foucault, dan Rorty) dan hermeneutik konstruktif (Heidegger, Gadamer, Ricoeur).

Untuk kepentingan karangan ini, penulis cenderung memilih menggunakan pengelompokan pemikiran hermeneutik ke dalam tiga gugus, yaitu pendekatan konservatif (misal, Schleiermacher, Emilio Betti, E.D. Hirsch), pendekatan dialogis (misal, Gadamer, Ricoeur), dan pendekatan kritis (misal, Habermas). Uraian berikut mengungkapkan serba ringkas gagasan utama dari masing-masing pendekatan tersebut.

\section{Pendekatan Konservatif}

Intisari gagasan pendekatan hermeneutik konservatif kurang lebih adalah sebagai berikut: (a) kebenaran teks merefleksikan maksud dari penulisnya atau makna asli yang ingin dipahami oleh pembaca; (b) kebenaran dipahami sebagai adanya kesesuaian antara gagasan penafsir dengan makna teks; (c) agar memperoleh kebenaran pesan yang terkandung dalam teks, orang perlu melakukan penelitian mengenai konteks historis di mana naskah itu ditulis. Pemahaman mengenai latar belakang sejarah, budaya dan kisah hidup penulis akan membantu orang dalam memahami makna teks; (d) untuk memahami kebenaran makna teks orang perlu memahami ragam dan bahasa teks, khususnya bagaimana kata-kata digunakan, dan apa maknanya bagi pendengar asli; (e) melalui penelitian sejarah dan penelitian bahasa, penafsir dapat menghindari adanya prasangka pribadi dan memahami teks 
sesuai dengan norma jamannya; (f) orang harus membedakan antara signifikansi teks (apa artinya bagi penafsir tertentu atau bagaimana hal itu relevan dengan tugas penafsir) dan makna teks ( makna objektif teks menurut patokan yang ada); (g) lingkaran hermeneutik berarti bahwa penafsir harus memahami bagian-bagian dari teks dalam kaitannya dengan keseluruhan teks. Hal itu meliputi pemahaman yang baik mengenai kata-kata pada tingkat mikro, kalimat, dan paragrap, sebagaimana pemahaman pada tingkat makro dari bagian-bagian teks dalam kaitannya dengan karya penulis dan karya-karya tulis sejaman dengan teks itu; (h) meskipun mungkin ada perbedaan sudut pandang antar-penafsir dalam memaknai teks, perbedaan ini pada prinsipnya dapat diatasi dengan mengedepankan standar berupa rasionalitas atau bukti-bukti (bdk. Blaikie1993:28-32; Sumaryono, 1995:35-62; Bertens, 2002:95-99).

\section{Pendekatan Dialogis}

Garis besar pokok-pokok pikiran pendekatan hermeneutik dialogis, kurang lebih adalah demikian: (a) kebenaran teks tidak mengikuti konsep mengenai kebenaran sebagai makna yang tepat, dalam arti adanya kesesuaian antara gagasan penafsir dengan maksud penulis dan/atau pemahaman pendengar asli. Mengikuti Heidegger, kebenaran dipahami sebagai semacam wawasan yang "diwahyukan". Kebenaran diperoleh dalam kegiatan membaca katimbang dalam bacaan/teks; (b) penelitian akademis mengenai konteks historis di mana teks itu ditulis memang dapat membantu orang dalam memahami teks, tetapi tidak boleh membatasi seluruh segi penafsiran. Pada akhirnya yang paling penting adalah daya upaya untuk membuat teks "berbicara" kepada situasi kekinian sang penafsir; (c) ada banyak penafsiran "keliru" terhadap teks, tetapi ada lebih dari satu penafsiran yang baik. Penafsiran bukan sama sekali bersifat subyektif, sebab teks itu sendiri akan memberikan batasan tentang sejauh mana kita dapat memahaminya; (d) penelitian sejarah dan bahasa akan membantu penafsir untuk memahami prasangka mereka sendiri, tetapi penelitian itu tidak akan menghilangkan semua prasangka. Kita tidak akan pernah dapat sepenuhnya menghindarkan prasangka untuk memahami teks sesuai standar jaman yang ada; (e) dengan membedakan antara signifikansi teks (apa artinya bagi penafsir tertentu atau bagaimana hal itu relevan dengan tugas penafsir) dan makna teks (makna objektif teks menurut standar yang ada), dapat dikatakan bahwa makna akan selalu dikondisikan oleh signifikansi dan tak akan pernah mencapai kesempurnaan atau kepenuhan; (f) lingkaran hermeneutik bararti bahwa penafsir membangun makna di atas teks, dan teks dapat menerima atau menolak makna tersebut. Pembentukan makna tersebut ditentukan oleh latar belakang dan prasangka penafsir. Teks mungkin menampilkan cakrawala sejarah atau budaya yang berbeda, sehingga menolak praanggapan atau pemahaman awal penafsir; (g) penafsiran yang berhasil, mensyaratkan adanya "percampuran cakrawala" (fuzion of horizon). Sebagian prasangka bersifat produktif, sebagian lagi tidak bersifat produktif. Penentuan mengenai mana yang produktif dan mana yang tidak produktif untuk penafsiran yang baik hanya dapat dilakukan dalam situasi hermeneutis. Tidak ada metode atau ukuran yang dapat menspesifikasikan lebih lanjut bagaimana penafsiran seharusnya dilakukan; (h) hermeneutik dialogis lebih bersifat deskriptif daripada preskriptif; (i) perbedaan sudut pandang dalam memaknai teks, tidak selalu dapat diatasi dan mungkin menjadi dasar penerimaan penafsiran yang berbeda-beda; (j) teks selalu bergerak melampaui penciptanya. Teks tetap terbuka dan tidak terbatas pada maksud si pengarang teks itu. Karena itu, penafsiran tidak bersifat reproduktif, tetapi produktif; (k) penerapan merupakan unsur penting dalam penafsiran. Pemahaman diperkaya melalui penerapan makna teks pada situasi baru. (bdk, Blaikie,1993:33-36; Sumaryono, 1995:63-79, 97-108, Bertens, 2002:162-171, 254-266). 


\section{Pendekatan Kritis}

Adapun inti pendekatan hermeneutik kritis, kurang lebih adalah sebagai berikut: (a) penafsiran pada dasarnya berpotensi terkendala dan terbiaskan oleh kekuatan sosial, politik dan ekonomi, termasuk dalam hal ini pertentangan kelas, ras dan gender; (b) untuk memahami secara penuh obyek yang akan ditafsirkan, atau untuk mencapai komunikasi yang tak terdistorsi dengan pihak lain (komunikasi bebas dominasi), orang tidak hanya perlu menaati prinsip-prinsip penafsiran yang tepat, tetapi juga memerlukan adanya penjelasan ilmiah tentang kenyataan sosial dan ekonomi yang menghambat penafsir; (c) tanpa adanya penjelasan ilmiah mengenai faktor-faktor real yang ada di balik kenyataan, hermeneutik akan gagal; (d) refleksi-diri dan hermeneutik-dalam (tiefenhermeneutik) dapat memperbaiki praktik komunikasi dan penafsiran kita; (e) dalam situasi perbincangan yang ideal, orang dapat mencapai komunikasi yang tak terdistorsi dan konsensus melalui penafsiran yang lengkap; (f) komunikasi / penafsiran memiliki kemampuan untuk memperluas cakrawala moral kita (bdk. Sumaryono, 1995:81-96; Bertens, 2002:242-254, 266-268).

\section{HERMENEUTIK DAN PRAKTIK PENDIDIKAN}

Dapat diringkas, bahwa hermeneutik pada dasarnya adalah refleksi kritis untuk menafsirkan teks/realitas dan memahami maknanya; melalui upaya tersebut cakrawala pemahaman orang mengenai dunia dan dirinya sendiri semakin diperluas dan diperdalam; lebih dari itu, melalui refleksi-diri orang diajak untuk membangun kebersamaan melalui dialog sejati, yaitu komunikasi yang tak terdistorsi / komunikasi bebas dominasi; orang juga diajak untuk selalu menerapkan makna yang diperolehnya ke dalam situasi baru demi memperkaya dan memperteguh pemahaman yang telah diperolehnya.

Dengan kata lain, melalui hermeneutik orang diajak untuk terus-menerus bergerak dari refleksi menuju aksi, demikian pula sebaliknya, demi pengembangan diri dan transformasi masyarakat/budaya secara bertahap dan berkelanjutan.

Dalam pemahaman semacam itu, tampak bahwa hermeneutik erat kaitannya dengan praktik pendidikan. Sebab, pada dasarnya praktik pendidikan adalah juga aksi pengembangan diri yang terarah pada aktualisasi-diri dan transformasi masyarakat/budaya secara intens dan berkelanjutan. Pendidikan adalah "pembentukan pribadi manusia dalam kaitannya dengan arah finalnya, dan sekaligus dalam kaitannya dengan kebaikan masyarakat, tempat orang yang bersangkutan menjadi anggota dan tempat dia harus meletakkan tanggung jawabnya sebagai warga dewasa" (Mardiatmadja, dalam Hartoko1990:36; bdk. Wolterstorff, 1980: 7-15).

Keterkaitan antara hermeneutik dan praktik pendidikan itu semakin eksplisit dalam pemahaman pendidikan kontekstual, bahwa "Pendidikan dan pengajaran bukanlah paket informasi yang disampaikan dengan pretensi dapat ditangkap terlepas dari konteks, melainkan komunikasi dalam konteks masyarakat, komunikasi dengan dan di tengah situasi hidup nyata. Melalaikan hal itu, kegiatan dan lembaga pendidikan akan menghambat seluruh proses learning...Pendidikan kontekstual ditandai dengan pembinaan kepedulian dan keterampilan analisis sosial, yang perlu dijalankan secara lintas ilmu, meliputi analisis sosial ekonomi, sosio-politis, sosio-kultural dan analisis personal. Titik tolak adalah konteks sosial konkret atau pengalaman hidup nyata" (Banawiratma, 1993:69,83. - cetak miring, penulis).

Demikianlah, pada dasarnya hermeneutik adalah sebuah keniscayaan dalam praktik pendidikan. Atau, minimal bisa dikatakan, bahwa hermeneutik potensial memberi inspirasi dalam kegiatan pendidikan, khususnya dalam praktik pembelajaran. Hal terakhir inilah yang tampaknya 
terwujud, misalnya, dalam pendekatan Pembelajaran Reflektif, sebagaimana dipaparkan secara menarik misalnya oleh Boyd dan Fales (1983), Boud et al. (1989), Peltier et al. (2005), dan dioperasionalkan secara padat oleh Drost (2001).

\section{Proses Refleksi}

Dalam konteks pembelajaran, menurut Boud et al. (1989:18-19) refleksi adalah tanggapan seseorang secara mendalam dan kritis atas pengalaman tertentu. Refleksi merupakan keseluruhan aktivitas pikiran (intektual) dan perasaan (emosional) seseorang dalam mengeksplorasi pengalaman. Melalui refleksi, orang semakin memahami makna dan konsekuensi dari pengalaman itu sehingga mampu memilih tindakan yang cocok untuk pengembangan diri maupun lingkungannya.

Secara garis besar, proses refleksi meliputi tiga tahap, yaitu: (a) menghadirkan kembali pengalaman: pada tahap ini, pembelajar mencoba mengumpulkan kembali peristiwa-peristiwa yang menonjol dan menghadirkan kembali peristiwa tersebut dalam pikirannya, tulisan atau pun cerita kepada orang lain; (b) mengelola perasaan: pada tahap ini ada dua kegiatan utama, yaitu memanfaatkan perasaan-perasaan yang positif dan mengubah perasaan-perasaan yang mengganggu; (c) mengevaluasi kembali pengalaman: di sini berlangsung empat proses penting, yaitu asosiasi, integrasi, validasi dan apropriasi. Asosiasi, adalah proses menautkan data baru dengan pengetahuan yang telah dimiliki. Integrasi, adalah proses mencari kaitan antara data yang ada. Validasi, adalah proses menguji otentisitas gagasan dan perasaan yang telah dihasilkan. Apropriasi, adalah proses mempribadikan pengetahuan baru.

Hasil dari proses refleksi bersifat kompleks, bisa berupa salah satu atau seluruh hal berikut: (a) sudut pandang baru dalam melihat pengalaman itu / gagasan baru; (b) perubahan sikap dan perilaku; (c) kesiapan untuk menerapkan sesuatu; (d) komitmen untuk melakukan tindakan tertentu (action). Hasil tersebut bisa baik atau kurang baik, bermutu atau kurang bermutu. Itu semua sangat tergantung pada niat dan kesungguhan pembelajar.

\section{Pembelajaran Reflektif}

Refleksi merupakan dimensi penting dalam pembelajaran (Dewey, 1933). Pembelajaran yang memberi perhatian pada dimensi refleksi disebut Pembelajaran Reflektif. Pembelajaran Reflektif merupakan pembelajaran aktif (active learning) yang berpusat pada siswa (Saptono, 2011: 91115).

Secara filosofis, Pembelajaran Reflektif didasarkan pada dua pandangan dasar, yaitu: (a). perlunya mengokohkan nilai-nilai manusiawi pada suatu bidang studi; (b). kaum muda perlu memperoleh kebebasan sewajarnya guna menempuh jalan hidup yang memungkinkan mereka tumbuhberkembang sebagai pribadi yang semakin dewasa (Drost, 2001: 1). Secara empiris, Pembelajaran Reflektif didasarkan atas kenyataan bahwa belajar efektif hanya terjadi lewat interaksi pelajar dengan pengalaman yang dimilikinya (sebelum memasuki kelas dan yang diperolehnya di ruang kelas). Sementara itu, interaksi dengan pengalaman itu akan bersifat produktif apabila itu berlangsung melalui refleksi, bukan melalui tindakan menghafal (Drost, 2001: 4).

Tujuan yang hendak dicapai melalui Pembelajaran Reflektif adalah: (a) membiasakan siswa berefleksi, dalam arti mau menjadikan pengalaman benar-benar sebagai guru; (b) mendorong siswa untuk peduli pada pengalaman-pengalaman manusiawi dengan segala makna dan konsekuensinya; (c) membiasakan siswa untuk membuat pilihan hidup dalam bentuk komitmen dan tindakan nyata. 
Pendek kata, Pembelajaran Reflektif merupakan proses pembelajaran yang peduli pada pembentukan hati nurani pembelajar sehingga mereka terdorong untuk bergerak dari pengetahuan (learning to know) menuju tindakan (learning to do) dan pemahaman diri yang makin otentik (learning to be). Dalam ungkapan J. Drost "berefleksi harus menjadi suatu proses yang membentuk hati nurani para pelajar, yaitu: sikap hidup sehari-hari, nilai-nilai dan keyakinan-keyakinan maupun cara berfikir dan bernalar, sehingga mereka didorong untuk bergerak melewati pengetahuan menuju tindakan (Drost, 2001: 3). Untuk itu, dalam Pembelajaran Reflektif guru berperan menyediakan kesempatan-kesempatan guna mendorong kreativitas siswa dan melatih mereka untuk berani merumuskan berbagai alternatif tindakan sebagai hasil dan tindak lanjut dari apa yang telah mereka pelajari, memilih tindakan yang paling mungkin dan melakukannya.

Di era "banjir informasi” seperti sekarang ini, Pembelajaran Reflektif menjadi amat relevan. Karena, pada umumnya siswa 'tahu banyak tentang banyak hal'. Meskipun demikian, hal itu sering kali tanpa disertai pemahaman mendalam mengenai makna dan konsekuensinya. Justru pada titik itulah, melalui Pembelajaran Reflektif, siswa diajak untuk mengembangkan kemampuan mendalami informasi hingga mampu memahami makna dan konsekuensinya bagi pengembangan diri mereka dan membuat mereka lebih peduli kepada sesama, lingkungan sosial maupun fisiknya. Melalui Pendidikan Reflektif, siswa diajak untuk membiasakan diri melakukan investigasi, tematisasi dan problematisasi sebelum mereka bertindak (Collins, 1999:150).

Secara lebih rinci, ada sejumlah alasan edukatif-praktis tentang perlunya Pendidikan Reflektif dipertimbangkan dalam praktik pembelajaran di sekolah (Drost, 2001:14-15), yaitu: (a) dapat diterapkan pada semua jenis kurikulum sebagai suatu sikap, mentalitas, dan pendekatan yang konsisten yang mewarnai seluruh proses pembelajaran; (b) dapat diterapkan tidak hanya pada disiplin-disiplin akademik, tetapi juga pada ranah non-akademik seperti kegiatan ekstra kurikuler, program pelayanan masyarakat, olah raga; (c) memungkinkan para guru untuk memperkaya baik isi maupun susunan bahan pelajaran. Demikian pula, siswa untuk belajar lebih aktif dan bertanggung jawab; (d) memungkinkan siswa menghubungkan bahan pelajaran dengan pengalaman mereka dan belajar dari pengalaman hidup mereka. Dengan demikian mendukung integrasi antara pengalaman belajar di kelas dengan pengalaman siswa di rumah, dunia teman sebaya, dan di masyarakat; (e) penerapan Pembelajaran Reflektif secara konsisten dan berkelanjutan akan membantu pembentukan kebiasaan berefleksi terlebih dulu sebelum melakukan sesuatu; (f) membangun kepekaan nurani terhadap hubungan-hubungan manusiawi, sehingga membuat siswa semakin peduli terhadap sesama.

\section{Pelaksanaan Pembelajaran}

Menurut Drost (2001: 5-13) ada lima langkah berurutan dalam pelaksanaan Pembelajaran Reflektif. Kelima langkah itu meliputi pengenalan konteks, penyajian pengalaman, refleksi, aksi dan evaluasi.

Pertama, pengenalan konteks. Pengalaman manusiawi, yang merupakan titik tolak dalam Pembelajaran Reflektif, tidak berlangsung dalam ruang hampa. Ia terjadi dalam sebuah konteks tertentu. Karena itu, guru perlu mengenali secara baik kenyataan-kenyataan kontekstual dunia siswa maupun dunia guru. Dalam hal ini, guru perlu mengenali secara baik konteks berikut: konteks nyata kehidupan siswa, konteks sosio-ekonomi-politik-kebudayaan yang merupakan lingkungan hidup siswa, konteks kelembagaan sekolah; dan konteks nyata proses pembelajaran.

Kedua, penyajian pengalaman. Pengalaman yang dimaksud di sini adalah setiap kegiatan yang bercirikan adanya pemahaman kognitif dari bahan yang disimak serta pelibatan dimensi afektif siswa. 
Di sini, pengalaman bisa dibedakan menjadi dua, yaitu pengalaman langsung dan tidak langsung. Pengalaman langsung adalah pengalaman real yang secara langsung dihadapi siswa. Pengalaman tak langsung adalah pengalaman real orang lain atau pengalaman rekaan.

Ketiga, refleksi. Refleksi di sini dipahami dalam pengertian khas, yaitu suatu upaya untuk menyimak dengan penuh perhatian terhadap bahan studi tertentu, pengalaman, ide-ide, usul-usul, atau reaksi spontan untuk mengerti pentingnya pemahaman mendalam sampai pada makna dan konsekuensinya. Melalui refleksi, siswa diajak untuk menggali makna dan konsekuensi dari suatu pengalaman. Tantangan terbesar bagi seorang guru adalah dalam hal merumuskan pertanyaanpertanyaan reflektif.

Keempat, aksi. Istilah aksi di sini merujuk pada pertumbuhan sikap batin dan tindakan yang ditampilkan siswa berdasarkan pengalaman yang telah direfleksikan. Dengan demikian, aksi mencakup dua langkah, yaitu: (a) pilihan-pilihan dalam batin (komitmen); dan (b) pilihan yang dinyatakan secara lahir (tindakan konkret/habitus).

Kelima, evaluasi. Pembelajaran reflektif tidak hanya peduli pada pertumbuhan dan perkembangan akademik, melainkan perkembangan pribadi siswa dan kepeduliannya kepada sesama. Karena itu, di samping evaluasi berupa tes, ulangan atau ujian, perlu pula dilakukan evaluasi otentik (authentic assessment) yang bersifat menyeluruh yang dilaksanakan sedikitnya sekali setiap semester. Evaluasi ini terutama sebagai sarana untuk melihat tingkat perkembangan perilaku dan kebiasaan siswa.

Agar pelaksanaan Pembelajaran Reflektif dapat berlangsung dengan baik, kiranya guru perlu memperhatikan beberapa hal berikut. Pertama, bahwa Pembelajaran Reflektif hakikatnya adalah 'belajar memaknai pengalaman'. Karena itu, perlu adanya sikap terbuka pada pengalaman-pengalaman manusiawi. Baik itu pengalaman siswa maupun pengalaman guru itu sendiri. Kedua, Pembelajaran Reflektif adalah pembelajaran aktif yang berpusat pada siswa. Maka, perlu ada keterbukaan dan apresiasi sewajarnya dari guru terhadap dunia kehidupan siswa dengan segala dinamikanya. Selain itu, perlu ada keleluasaan secukupnya bagi siswa untuk menggali kedalaman pengalamannya sehingga mereka menemukan sendiri makna dan konsekuensi dari pengalaman itu. Ketiga, dalam praktik Pembelajaran Reflektif, semaksimal mungkin guru perlu waspada terhadap kecenderungan-diri untuk bersikap “manipulatif” dan indoktrinatif kepada siswa. Keempat, supaya praktik Pembelajaran Reflektif makin bermutu, guru perlu merefleksikan pengalamannya sendiri setiap kali usai melangsungkan pembelajaran. Dengan cara demikian, diharapkan ia akan menemukan gagasan, sudut pandang, komitmen dan bentuk unjuk kerja baru secara kontekstual.

\section{PENUTUP}

Setiap kali hermeneutik dipandang sebagai wacana filsafat yang mengawang-awang dan jauh kena-mengenanya dengan dunia pendidikan. Uraian sederhana di atas mengindikasikan bahwa hermeneutik memiliki kena-mengena dengan pendidikan. Bahkan, kena-mengena itu tidak sebatas pada dataran teoretis, tetapi juga praktis. Hermeneutik, manakala dipahami dalam perspektif praktik pendidikan, tak lain adalah seni sekaligus metode untuk mencari makna dalam segala pengalaman manusiawi untuk membangun kehidupan bersama yang berkeutamaan.

Meminjam ungkapan Wolterstorff(1980), hermeneutik tak lain adalah perkakas pendidikan yang memungkinkan berlangsungnya: educating for responsible action. Sayangnya, ia kurang memperoleh apresiasi sewajarnya dalam praktik pendidikan kita. Mengapa hal itu bisa terjadi? Entahlah. Yang jelas, kini dunia pendidikan kita terkesan makin abai terhadap pentingnya mengolah 
pengalaman manusiawi sesehari. Padahal, sejatinya itu merupakan bahan dasar teramat penting dalam pendidikan.

\section{DAFTAR PUSTAKA}

Banawiratma, J.B.1993. Iman, Pendidikan dan Perubahan Sosial. Yogyakarta: Kanisius.

Bertens, K. 2001. Filsafat Barat Kontemporer: Perancis. Jakarta: Gramedia.

Bertens, K. 2002. Filsafat Barat Kontemporer: Inggris-Jerman. Jakarta: Gramedia.

Boud, David et. all (Ed).1989. Reflection: Turning Experience into Learning. London: Kogan Page.

Boyd, Evelyn M. dan Fales Ann W. "Reflective Learning: Key to Learning from Experience" Journal of Humanistic Psychology, Vol 23, No. 2, Spring 1983:99 - 117.

Collins, Denis.1999. Paulo Freire: Kehidupan, Karya dan Pemikirannya. Yogyakarta: Pustaka Pelajar.

Dewey, J. 1933. How we think: A restatement of the relation of reflective thinking to the education process. Boston: D. C. Health.

Drost, J. 2001. Ignatian Pedagogy: A Practical Approach. Jakarta: (tidak dipublikasikan).

Freire, Paulo.1985. Pendidikan Kaum Tertindas. Jakarta: LP3ES.

Howard, Roy J. 2000. Hermeneutika: Pengantar Teori-Teori Pemahaman Kontemporer. Jakarta: Nuansa.

Moeller-Vollmer, Kurt.1985. The Hermeneutics Reader: Text of the German Tradition from the Enlightenment to the Present. New York: The Continuum Publishing Company.

Neuman, W. Lawrence.2002. Social Research Methods, Qualitative and Quantitative Approaches. Boston: Allyn and Bacon.

Peltier, James W.; Hay, A. dan Drago, W. “The Reflective Learning Continuum: Reflecting on Reflection” Journal of Marketing Education, vol 27, No.3, Desember 2005: 250-263.

Ricoeur, Paul.1991. From Text to Action: Essays in Hermeneutics II. (translated by Kathleen Blamey and John B. Thompson). Evanston, Illionis: Northwestern University Press.

Saptono. 2011. Dimensi-dimensi Pendidikan Karakter: Wawasan, Strategi dan Langkah Praktis. Jakarta: Esensi-Erlangga Group.

Sugiharto, I. Bambang.1996.Postmodernisme: Tantangan Bagi Filsafat. Yogyakarta: Kanisius.

Sumaryono, E.1995. Hermeneutik: Sebuah Metode Filsafat. Yogyakarta: Kanisius.

Usher, Robin \& Edwards, Richard.1994.Postmodernism and Education: Different voices, different worlds. London: Routledge. 
Satya Widya Vol.28, No.1, Juni 2012: 73-82

Van Peuersen, C.A.1985. Orientasi di Alam Filsafat. Jakarta: Gramedia.

Wolterstorff, Nicholas.1980. Educating for Responsible Action. Grand Rapids: CSI Publications \& Wm.B. Eerdmans Publishing Company. 